Article

\title{
An Analysis of Irrigation Organizations in Colombia through the Prism of Collective Action
}

\author{
Juan Patricio Molina-Ochoa ${ }^{1}$, Rosa Gallardo-Cobos ${ }^{2}$ (I) and Pedro Sánchez-Zamora ${ }^{2, * \mathbb{C}}$ \\ 1 Departamento de Desarrollo Rural, Facultad de Ciencias Agrarias, Universidad Nacional de Colombia-sede \\ Bogotá, Bogotá 111321, Colombia; jpmolinao@unal.edu.co \\ 2 Department of Agricultural Economics, Sociology and Policy, ETSIAM, Universidad de Córdoba, \\ Córdoba 14014, Spain; rosagallardo@uco.es \\ * Correspondence: pedro.sanchez@uco.es; Tel.: +34-957-218444
}

Received: 26 September 2019; Accepted: 29 October 2019; Published: 1 November 2019

\begin{abstract}
The objective of this article is to deepen the knowledge of collective action in irrigation organizations in Colombia, by identifying the limitations of the members for their organizational work and the variables of context that determine collective behavior. Human and environmental factors have not been sufficiently considered in public irrigation policies, since, in the case of Colombia, these have focused almost exclusively on the physical infrastructure. The methodology develops a qualitative approach based on an ethnographic and quantitative study of the socioeconomic characteristics of irrigation users. The results allow us to affirm that the collective awareness of water is a common good. The vision of the associates about the associative work, the conformation and structuring of the organizations, the nature of the established agreements, and the socio-economic, environmental, and political environment of the organizations studied, are determining factors of their collective action and, therefore, should be taken into account in public policies of associative irrigation.
\end{abstract}

Keywords: collective action; irrigation organizations; Colombia; rural development policies

\section{Introduction}

The study of associative irrigation districts implies placing oneself into the concept of the common, referring to the social practices, values, and norms that a community establishes to manage the sustainable use of its resources [1]. Thus, by transcending the material sphere, the importance of two other dimensions of the common good can be recognized: the social one, represented by the community committed to managing it, and the institutional one, referring to the agreements established for its use [2].

The social dimension implies a collective action, understood as the set of activities and the coordinated effort of several individuals who interact spontaneously or through the intervention of an external institution [3].

With this perspective, the capacities of local communities to establish agreements to manage their resources, without state or private intervention, are recognized [4-6]. This questions previous theories, which state that individuals put their economic and selfish rationality before cooperation. Being indispensable, for example, is the prevalence of either public or private intervention, as emphasized by Hardin [7], or the application of incentives, as affirmed by Olson [8].

However, collective action presents challenges. By focusing on common purposes, private interests would come into conflict with collective interests, and some individuals would be tempted to benefit from the efforts of others. This problem, referred to as the free rider effect [8,9], led to the identification of factors that affect the sustainability of collective action, such as the size, heterogeneity, proximity, experience, and objectives of the group [10]. One recognizes that the scales and actors vary, but the 
collective dilemma is the same [11]. Thus, the formulation of game rules in accordance with local conditions, the definition of limits for the use of the common good, the application of conflict resolution mechanisms, the enactment of penalties for non-compliance, and the respect for the autonomy of communities all become heightened [5]. This would take place in a scenario of multiple levels of entities involved in the process. Añaños [1] draws attention to the role of these entities, such as local or national governments, because they may or may not create the conditions for communities to build their institutions.

Following this line of analysis, authors such as Fonseca [12] reiterate the importance of social capital as a necessary condition for the success of collective action. By referring to links governed by values such as trust and reciprocity and, consequently, by norms of interaction between individuals, social capital favors cooperation and individual capacity to solve problems of collective action [13-15].

Since the characteristics of individuals are critical for understanding social capital, the approach for the notion of human capital is indispensable. Although the demographic structure and educational training are variables used for defining human capital [16], the capacities of individuals should also be considered due to their impact in favor of social agreements [17]. Likewise, since environments for favorable interaction are required, the study of the context, both internal and external, is significant for understanding social and human capital [18,19].

Recognizing the interaction between human and social capital and its importance for collective action poses a challenge for developing organizational theories that take into account individual capacities. This perspective, which gives more attention to the strengthening of the human component, emphasizes that only investing in the physical infrastructure hardly guarantees that the desired effects will occur [10].

This is the case in Colombia, where rural development policies have had an increase in agricultural productivity among their various purposes by promoting irrigation districts, executed by associations of small producers. These associations would be responsible for the construction, operation, and maintenance of works for the collection, conduction, and distribution of water, as well as for its sustainable use. In the initial phases of this process, difficulties were evident among the organizations for fulfilling the commitments acquired. This raised concerns about the strength of the group and the sustainability of the irrigation infrastructure.

Thus, associative work has been conceived as a fundamental and alternative pillar for rural development in Colombia [20-22]. Understood as an instrument of social and group cohesion, it provides small producers with benefits, such as increased productivity through economies of scale, ease of access to resources, and greater insertion and negotiation power in the marketplace [23,24]. However, organizations face problems difficult to overcome. According to studies carried out especially for cooperatives and associations of small producers, these problems refer, among others, to the distrust between actors, a lack of associative education, low participation, inefficiency and dishonesty of some leaders, low capitalization capacity, and slow turnover of management positions [21]. As a result of these difficulties, the role of these organizations as an instrument of rural development has been questioned [23].

This scenario, which highlights the relevance of the human dimension in terms of values, capacities, education, participation, and leadership, invites research for deepening knowledge of collective action from a perspective that incorporates aspects of the individual orbit in relation to organizational functioning. The theory of collective action provides useful conceptual developments for this purpose, by connecting the individual or human capital perspective with the collective or social capital perspective, without losing sight of the context in which they are inserted. This supports a broad look, and integration and understanding of the factors that affect them. According to these ideas, a framework for the analysis of collective action is illustrated in Figure 1. 


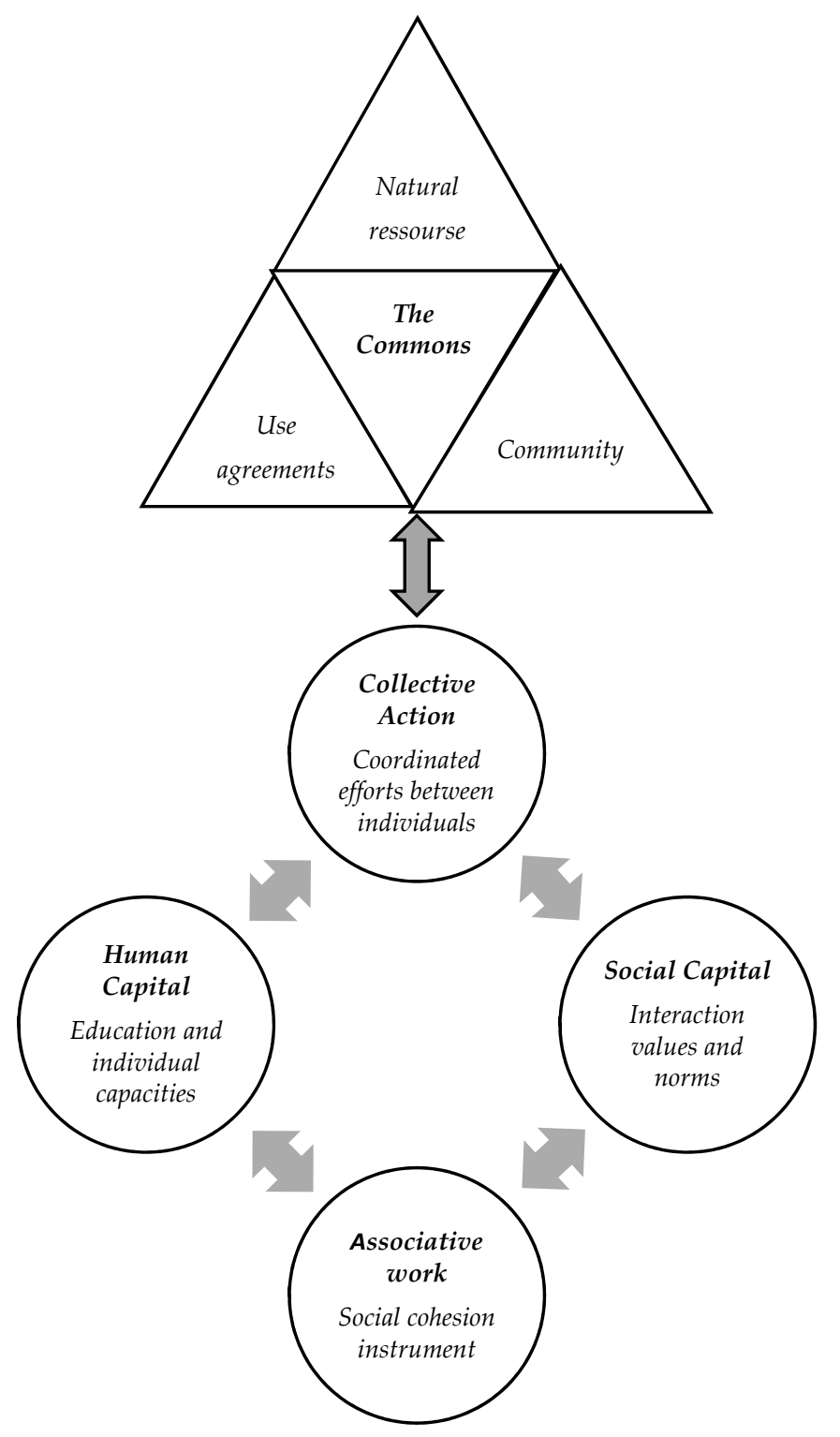

Figure 1. A framework for the analysis of collective action.

Previous collective action work relevant for this research is mainly concerned with empirical evidence from case studies in different countries. These studies identify factors that influence collective action and help explain its successes and failures. They also provide frameworks for analysis and invite a discussion on the relationship between organizations and the specificities of the context in which they are located [5].

The available literature on associations of small agricultural producers in Colombia refers mainly to the diagnosis of the problems they face in order to assume their productive and commercial challenges. However, further deepening of its causes is required by addressing specific studies that allow us to understand the particularities of collective action such as in the use of water for irrigation.

Given this reality, this work is proposed with the objective of examining the factors that limit establishing solid collective action within the irrigation organizations in Colombia. To achieve this, it was necessary to study the characteristics of their associates and the environment in which they operated, as well as the particularities of the collective work of the organizations during the construction phase of the irrigation districts. 
The results obtained contribute to understanding the organizational dynamics of small irrigation producers in Colombia, so that both the communities and the State have an analysis of human factors that affect lasting collective action.

\section{Materials and Methods}

The mixed methods approach combining quantitative and qualitative methodologies was used to achieve complementarity in analyzing the results [25].

Twenty functioning organizations of new publicly funded irrigation districts were studied in 2012, located in 19 municipalities in the Andes mountain range in Northern, Central, and Southern Colombia, as shown in the map in Figure 2. These organizations were mostly made up of small farmers who had the possibility of accessing state resources for the first time as being part of an associative irrigation system. The study population corresponded to the universe of users and their respective organizations financed with public resources for the construction of the works. The quantitative information was obtained through a census of 2184 irrigation users and the qualitative one addressed all 20 organizations. This means that information was collected from all the beneficiaries of the associative irrigation policy in Colombia during that period.

Obtaining quantitative information, carried out during the construction of the projects, allowed the identification of the social, economic, commercial, organizational, and technical characteristics of the producers, as well as the conditions of the context in which their organizations operated. In qualitative terms, the field work had an ethnographic approach and involved a four-month stay in the territories where 12 of the 20 organizations were located. Initially, bonds of trust were generated with the communities and then interviews were conducted with key actors, focused on learning about the organizational dynamics and their perceptions of the environment and collective work.

A participant observation technique was also used following the phases described by Angrosino [26]. In the remaining eight organizations, in which ethnographic work was not possible for logistical reasons, focus groups were held to learn opinions on irrigation districts and state services available in the territories of the organizations.

To complement the findings obtained with the quantitative method on the socio-economic characteristics of the associates and their context, qualitative information allowed for a better understanding of the functioning of the organizations during the construction phase of the projects. In order to know the collective work of the associations, the following guiding questions were addressed with their members: Why did they decide to form organizations? How did the association process work? What were the main problems faced and what achievements were met with the collective work?

Systematization of the responses was done by grouping topics that were input for the construction of the analysis categories, which would allow an improved understanding of the approaches and perceptions of the producers, as well as the identification of the collective action determinants. This method of studying the results sought to ensure consistency between the questions asked and the corresponding categories of analysis. This is how individual motivations largely explain the reasons for organizing, as explained in the results and in the discussion. The structuring and conformation of organizations highlight crucial aspects of the associative process. Participation and leadership bring together the main problems experienced by producers, and the values synthesize the most recognized achievements by the members of the organizations, thanks to their collective work.

Self-made survey designed for this research using Microsoft Word. Information collected and digitized in Microsoft Excel. 


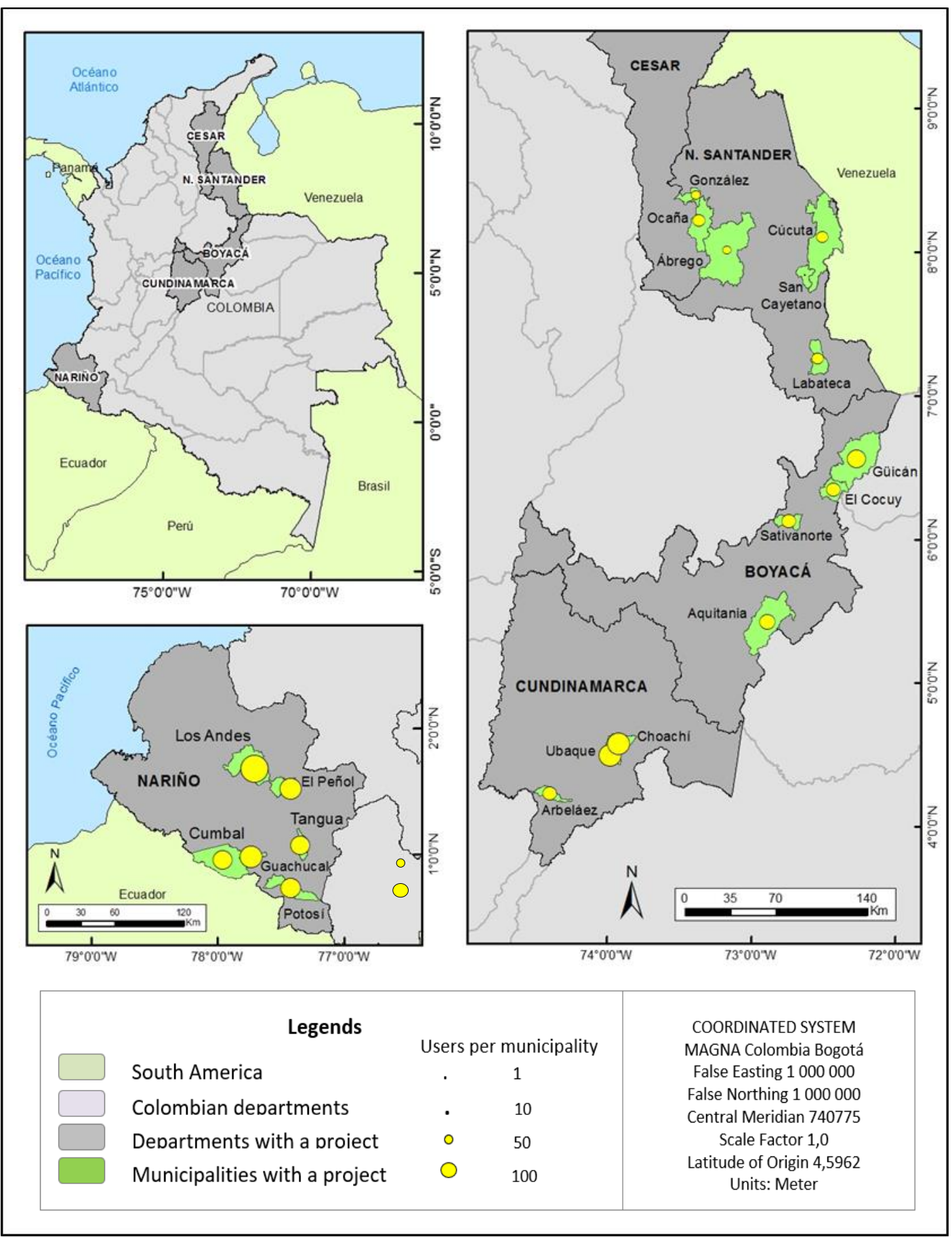

Figure 2. Study area by departments and municipalities showing the number of users among the organizations of irrigation districts.

\section{Results}

The results of the research illustrate the existence of individual, organizational, and environmental factors that influence the consolidation of collective action. It is necessary, therefore, to distinguish results relating to the context of those involved in collective work practices that were developed and implemented by the members of the associations during the construction phase of the irrigation districts. 


\subsection{Characteristics of Members of Organizations and Their Environment}

To carry out a more comprehensive analysis of the organizations, characteristics of their members were considered, as well as the economic, social, and institutional conditions of the organizational environment.

\subsubsection{Economic Characteristics}

Irrigation organizations were made up of small farmers, mostly (78.5\%) engaged in agriculture on farms under a Family Farming Unit (FFU or UAF in Spanish) (96.4\% of users). The UAF, defined as the agricultural enterprise with an extension that could generate at least two monthly legal minimum wages, would allow the family to remunerate its work and have additional capital for forming its assets [27]. Therefore, they are poor producers, smallholders, and landowners (80\%) with an average time of permanence on their land of 14 years and with a prevalence of family labor $(65 \%)$ compared to hired workers (32\%). Figure 3 presents the graphs constructed from the data, which shows the time and conditions of the land tenure.

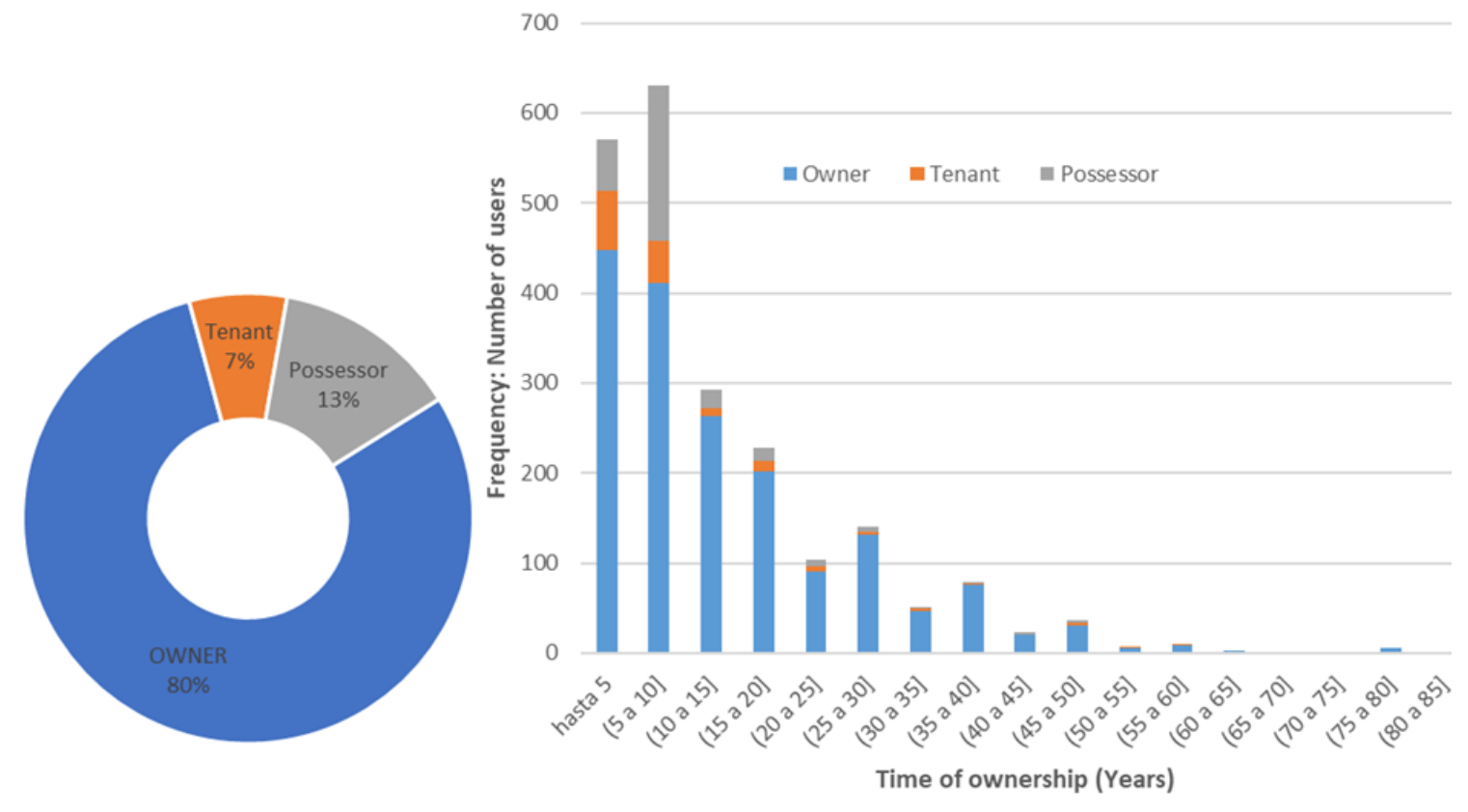

Figure 3. The land tenure condition and time.

Technological practices included the use of certified seeds ( $22 \%$ of producers) and improved seeds $(13 \%)$, as well as synthetic chemical inputs for the control of pests and diseases $(25 \%)$, which were applied without technical guidance. In the face of irrational use of inputs, the producers recognized the importance of sustainable practices and relevant technical assistance.

More than the natural conditions and the provision of services and infrastructure, the market was perceived by producers as the main factor affecting their activity, as presented in Figure 4.

The fact that almost all of the farmers (between $91 \%$ and 100\%) sold their products in territorial markets (shown in Figure 5) made them vulnerable to local intermediaries.

In this traditional distribution system, intermediaries imposed the conditions of purchase and sale in scenarios of high price variability and low bargaining power of the producers. Faced with this reality, there was a type of helplessness.

"The intermediaries pay as they want, the market price may be expensive, but they offer to pay as if it were a gift (... ), they keep all the money. The field does not! In the face of the producers, they sell at double the price (...), there is no stable price".

(Interviewee 1) 


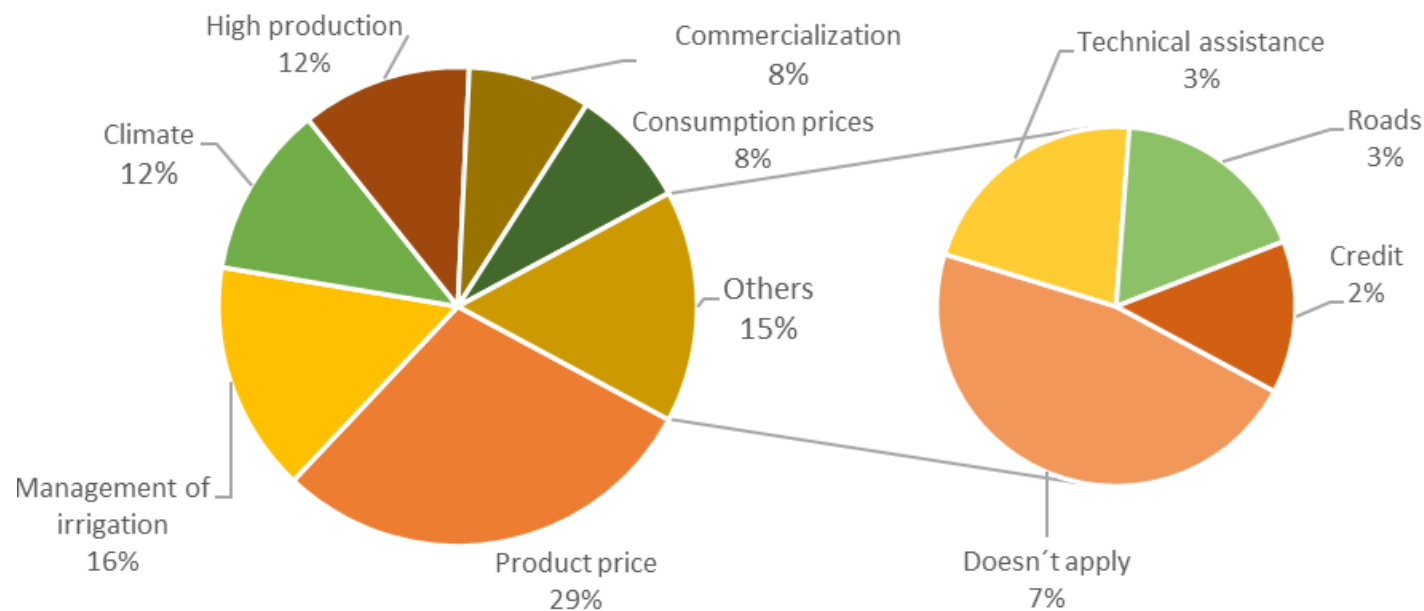

Figure 4. Factors determining the success of productivity based on the census of users of the irrigation districts.

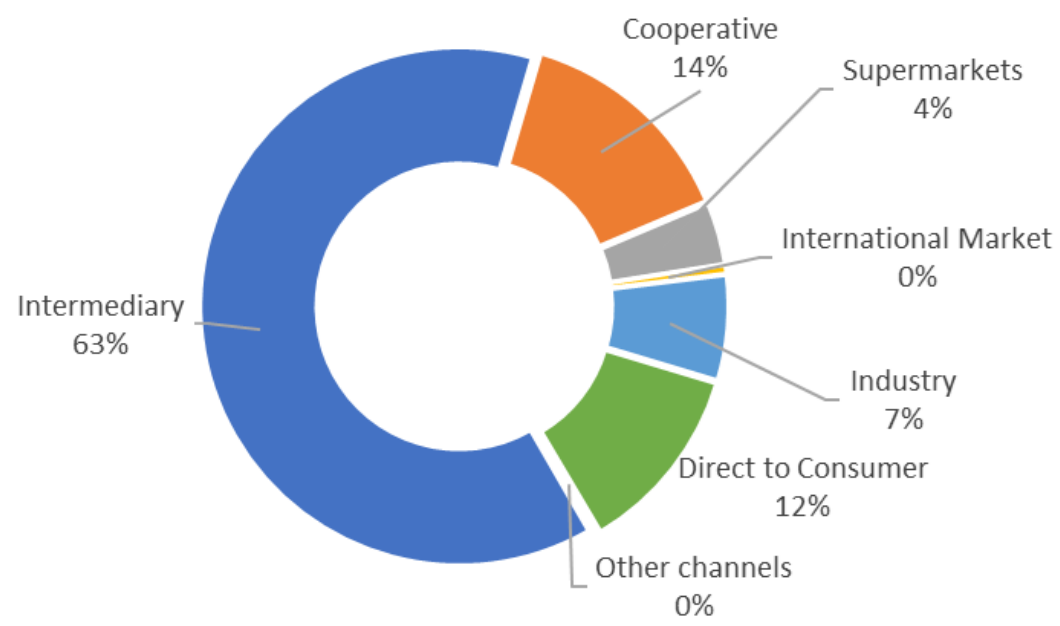

Figure 5. Destination of production.

For the producers, the selling price was the main source of uncertainty about the future of their activity.

"Prices are a lottery. Today, they can be good and tomorrow super cheap (...) agriculture here is dependent on luck. You lose ten and win one".

(Interviewee 2)

Despite this, the producers continued to produce with the expectation that prices would improve. This hope was called "revenge." They cultivated by tradition, or "cultivated as a vice," as some resignedly stated.

Inequitable trade relations were also explained by the low availability of their own transport, which was a source of power for intermediaries. In the opinion of the producers, this reduced their chances of access to markets and their negotiating capacity.

It is striking that, despite these difficulties, producers maintained traditional channels as the only commercialization option. Figure 6 shows how only $14 \%$ of respondents were inclined to hear new proposals, and even lower was the number of those who were interested in making collective marketing agreements. 

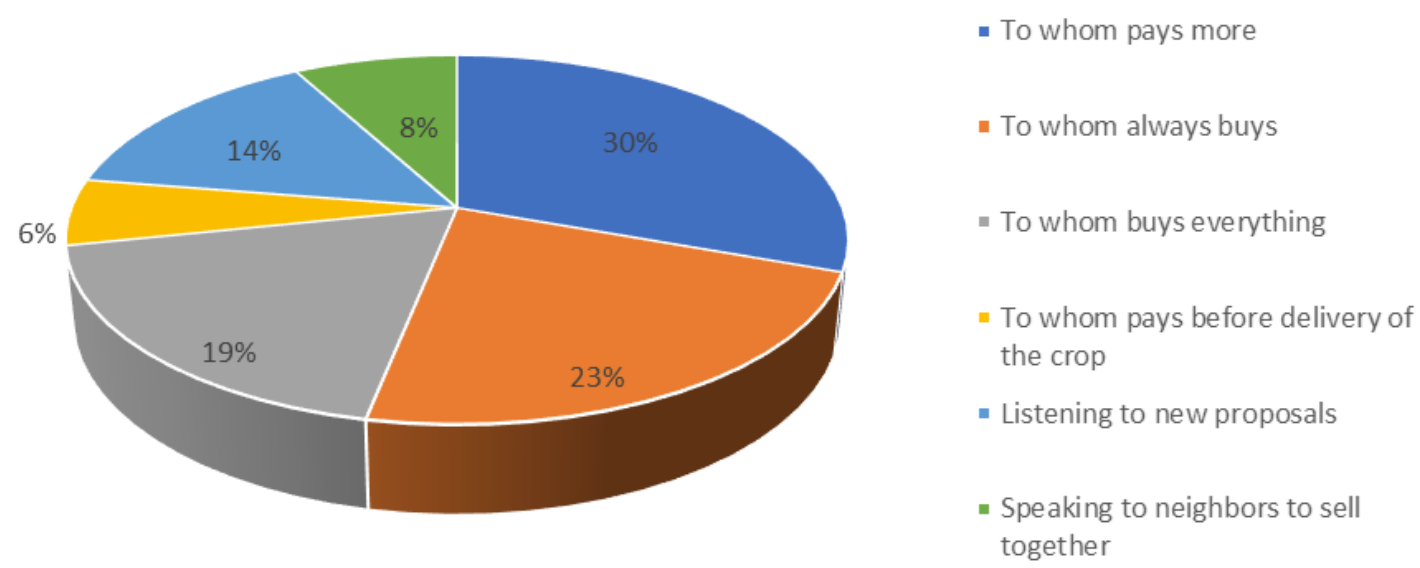

Figure 6. Features to choose the buyer.

Producers also expressed concern over production costs. They stated that it was common to sell their crops at the same price as the purchase of inputs, along with losing their work and that of their family, as well as the time and money invested (Focus Group 1).

According to these testimonies, agriculture was not perceived as a profitable activity. Affected by conditions of poverty, limitations in the size of the land and access to technology, and subject to the inefficiencies of the markets, their social environment was one of resignation. Hence, the motivations with irrigation collided with this reality, which determines the incredulous attitude of the producers, accustomed to defending themselves alone.

\subsubsection{Social Characteristics}

The organizations were constituted mainly by men (two thirds of the members) with an average of 51 years, who represented the beneficiary households of the irrigation district, conformed by an average of four people, who were predominantly older adults and children.

According to information presented in Figure 7, there was a low presence of young people in the families, which could be explained by rural migration, originating in conditions of poverty, lack of opportunities, and low access to services. In the opinion of the producers, this reality would have future implications on generational change, culture, family unity, and vulnerability in old age.

Information in Figure 8 shows the low educational level of the associates in which $9 \%$ had no formal education and $64 \%$ had a primary education, with women having the lowest educational level.

Another determining aspect of rural marginality was the armed conflict, which has affected the country for decades. In a climate of violence and with the use of intimidation to establish relations of power and territorial control, the complex reality of forced displacement and rural migration was experienced. An atmosphere of distrust was established that favored the predominance of an individual perspective over the collective one and the rupture of community ties.

This phenomenon was influenced by the devastating impacts of illicit crops such as the decrease in food production, a culture of easy money, social degradation, and the substitution of the legal economy with the illegal one with its sequels of insecurity.

In summary, the low educational indicators, the processes of migration, and the social disintegration that affected the environment of irrigation organizations, constituted a challenging scenario that added complexity to collective action and to the formation of human and social capital. 


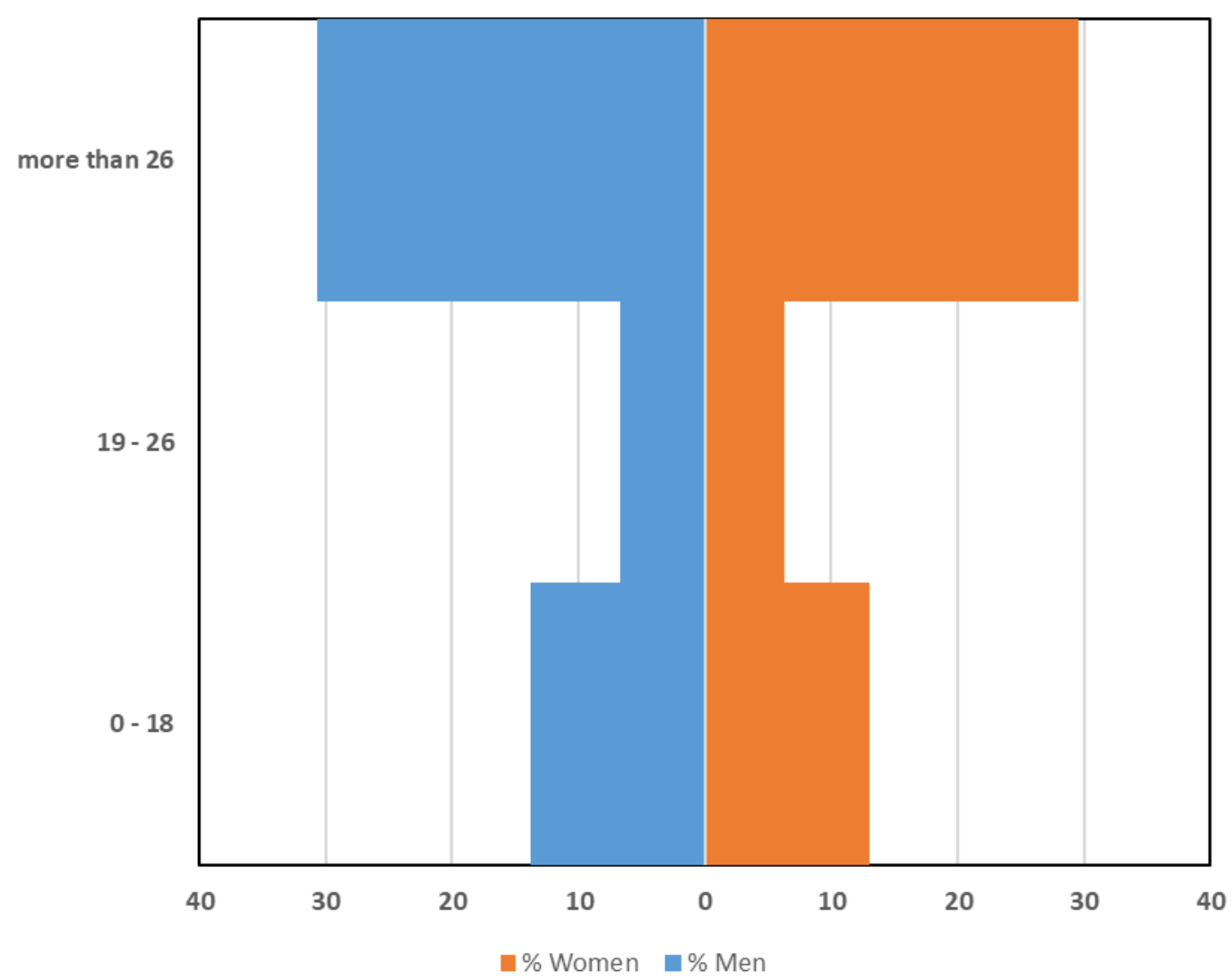

Figure 7. Sex and age of the members of the families in the irrigation districts.
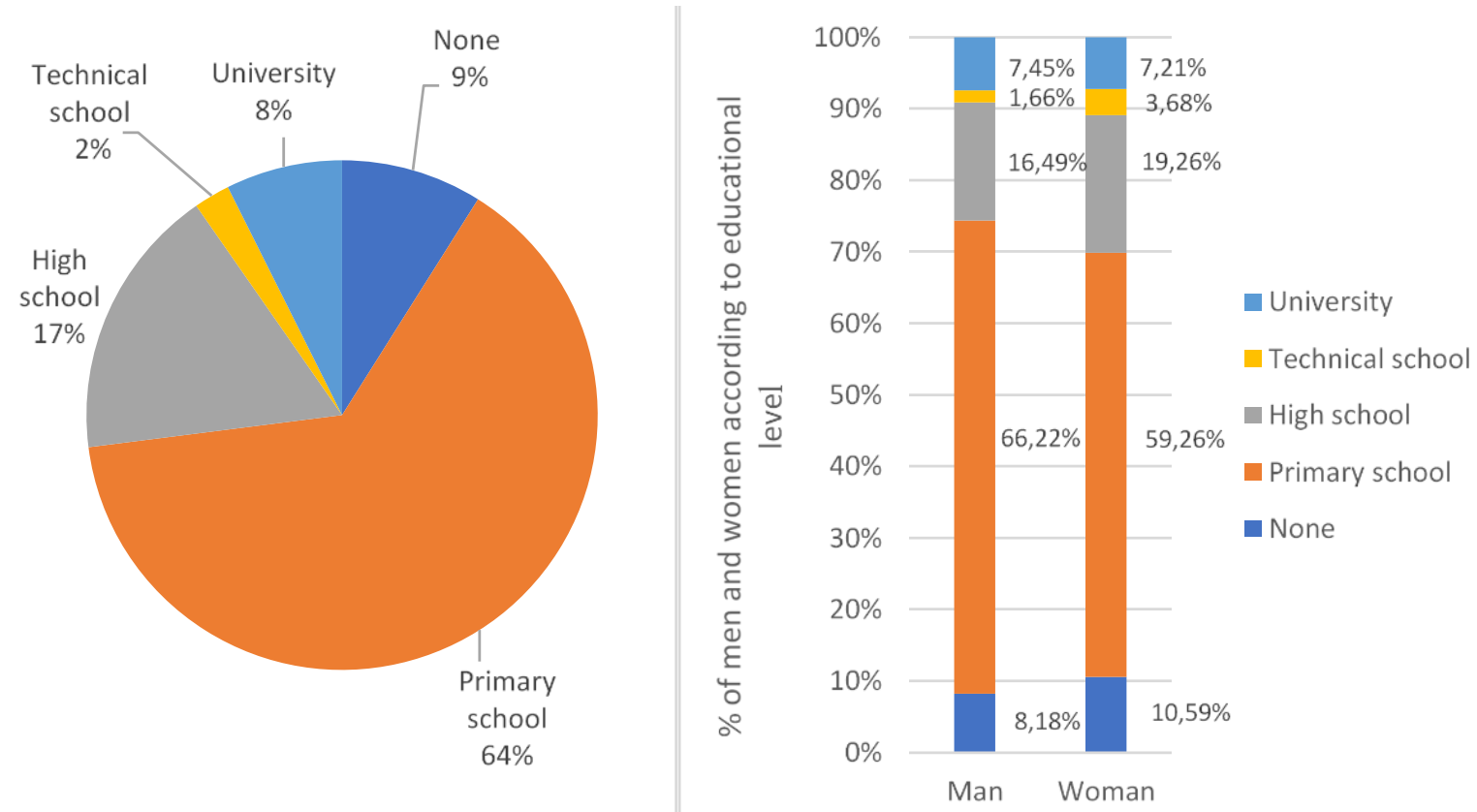

Figure 8. Educational level of the associates segregated by sex.

\subsubsection{Political and Institutional Characteristics}

In the context of uncertainty in which rural communities live, their relationship with the State and its policies is of vital importance. The producer sees the State as being responsible for attending to its basic and infrastructure needs. 
Although, for the members of the organizations, the investment of the State in irrigation meant that they were included in national policies. They also considered that, without comprehensive policies, the irrigation infrastructure would be insufficient. The producers stressed that, to achieve comprehensive policies, economic services should be prioritized, including support for commercialization $(25 \%$ of producers) and improvement of roads $(17 \%)$, and social services, such as access to drinking water $(16 \%)$, health $(16 \%)$, housing $(9 \%)$, and education $(6 \%)$. Likewise, the producers highlighted the need for environmental protection programs and for the State to assume these initiatives.

In sum, producers expected direct responses from the State for the multiple needs of their immediate reality. They longed for a correspondence of policies to all the dimensions of their rural world in the economic, social, and environmental spheres. However, as part of their priorities, they did not contemplate the State's support for associativity.

\subsection{Collective Work during the Construction of Irrigation Districts}

In order to identify the factors that limit collective action in irrigation organizations, it is necessary to complement contextual and individual characteristics by studying collective work based on partner roles in their organizations and the perceptions about them. Motivations, values, participation, and leadership are categories of analysis that reflect the central aspects of these perceptions. In addition, these categories are an integral part of the collective work. In this scenario, results of the research also show, as another analytical category, the relevance of the normative aspects that determine the conformation and structuring of the organizations considered in this study.

These categories of analysis have similar characteristics in all regions of the study area. These regions are dominated by a peasant economy and family-based agriculture of smallholders located in mountain areas, who live in conditions of poverty, according to the contextual information presented in the previous sections. Although cultural aspects mark differences between regions, the scope of this research did not allow these particularities to be clarified.

\subsubsection{Individual Motivations}

Motivations expressed by producers were both immediate and longer-term, and they played a decisive initial role in organizational actions.

From the short-term and immediate perspective, the intention of forming organizations prevailed in order to meet the requirements of public policy for taking advantage of State resources and for gaining permanent access to water. The aim was to face the threats of climate variability, eliminate seasonal production, and recover agricultural activities affected by droughts from previous years (95\% of respondents). Expectations focused on the introduction of changes in agricultural production practices such as improving product quality, diversifying, producing at other times, and achieving efficient soil management.

Furthermore, benefits expected by the producers opened up the alternative of generating added value and technological changes. They visualized irrigation as "the first of the new technologies to be implemented for a production with better technology" (Focus Group 2). They hoped that the new generation of young people would assume the necessary transformation to overcome the precariousness of life in the countryside. "We all want [the sons] to go and be better, and if they want to return to the countryside, they must bring technology" (Focus Group 1).

The motivations derived from the changes in the future showed an interest in new non-agricultural activities (24\% of those interviewed). Those who maintained their productive intention focused on livestock activities of small animals $(70 \%)$, such as pigs and hen, while only $6 \%$ had an interest in improving agricultural and crop productivity. This denoted a contrast with the purposes of irrigation policy that was more focused on increasing crop productivity.

Future motivations also expressed an intention for greater social significance of organizations. For some, the districts represented a "way to promote the generation of development, progress, and prosperity in the territories" (Focus Group 3), while, for others, an interest was clear for leaving "a 
legacy for future generations and recovering part of their culture" (Focus group 4). Likewise, some members of the indigenous population expected a contribution from their irrigation organizations for the recovery of elements of their local culture such as traditional crops (Focus Group 5). Additionally, organizations were also seen as a means to gain experience in the management of collective demands facing public authorities.

Due to their interest in organizing around irrigation, the producers combined different types of motivations associated with productive purposes, and wishes for well-being and development, including intergenerational, which highlight two aspects. On the one hand, there is a challenge for organizations to meet and reconcile the variety of motivations of its members and, on the other hand, the need to examine and rethink visions of public policy that, because of its concern on increases in agricultural productivity, lacks coherence in terms of beneficiary motivations of associative irrigation. This would suggest a more flexible policy approach.

\subsubsection{Formation and Structuring of Organizations}

A second aspect that influences collective action relates to organizational practice. A precarious associative experience was identified. Although $34 \%$ of producers had organized at the same time for agricultural activities, they did not respond to a solid and continuous organizational structure. This fact agrees with testimonies about the lack of an associative culture and a preference for individual work.

It should be added that the formation of organizations responded to state initiatives and not to spontaneous community processes. By favoring the fulfillment of formal requirements for access to public incentives, the actions of the members in the group were limited to signing minutes $(76 \%$ of the interviewees) or verbal agreements $(6 \%)$. Other members $(18 \%)$ said they received payments to encourage their participation and to meet a minimum number of users.

These reasons for being associated show a top-down approach in forming organizations, which is explained by the irrigation policy having an indispensable requirement that small producers create associations. How to do this was not the main concern. The important thing was to constitute the organization that would support the request for irrigation to the government and, in this way, the financing could be obtained. This explains the fact that some producers were paid to become part of the organization. It was not the procedure that was important. As part of that public policy-induced process, producers responded reactively, accommodating requirements and limiting the scope of their participation, at least initially, to that sole purpose. In that dynamic, different scenarios could arise. Thus, the initiative to apply for financing could come from a producer with a certain leadership capacity to bring others together, from a politician with electoral motivations, from a builder interested in a work contract, or from a government agency committed to public policy.

In spite of the difficulties in setting up the organizations and the little associative experience, the public policies assigned them the responsibility of executing the projects, contacting the builders of the works, verifying the fulfillment of their tasks, and reporting to the State on the resources used. Fulfilling these responsibilities implied for the organizations a series of challenges for which they were not prepared for and for which prior accompaniment would have been required. This situation resulted in internal problems that, in turn, hindered their ability to achieve their objectives.

\subsubsection{Participation and Leadership}

According to the leaders of the organizations, there was low participation of the base members, expressing little commitment to the activities that they had to carry out individually and collectively. Additionally, there was non-compliance with the agreed labor contributions, non-attendance at meetings, and lack of disposition to assume managerial responsibilities.

Assessments of the leaders contrasted with those of the base members. In addition, $90 \%$ of the associates stated that their main activity in the organization consisted of attending meetings, which, in their opinion, meant participation in decision-making ( $66 \%$ of those interviewed). However, as 
illustrated in Figure 9, a low commitment to crucial and mandatory activities was recognized, such as the contribution of labor that was made only by half of the partners.

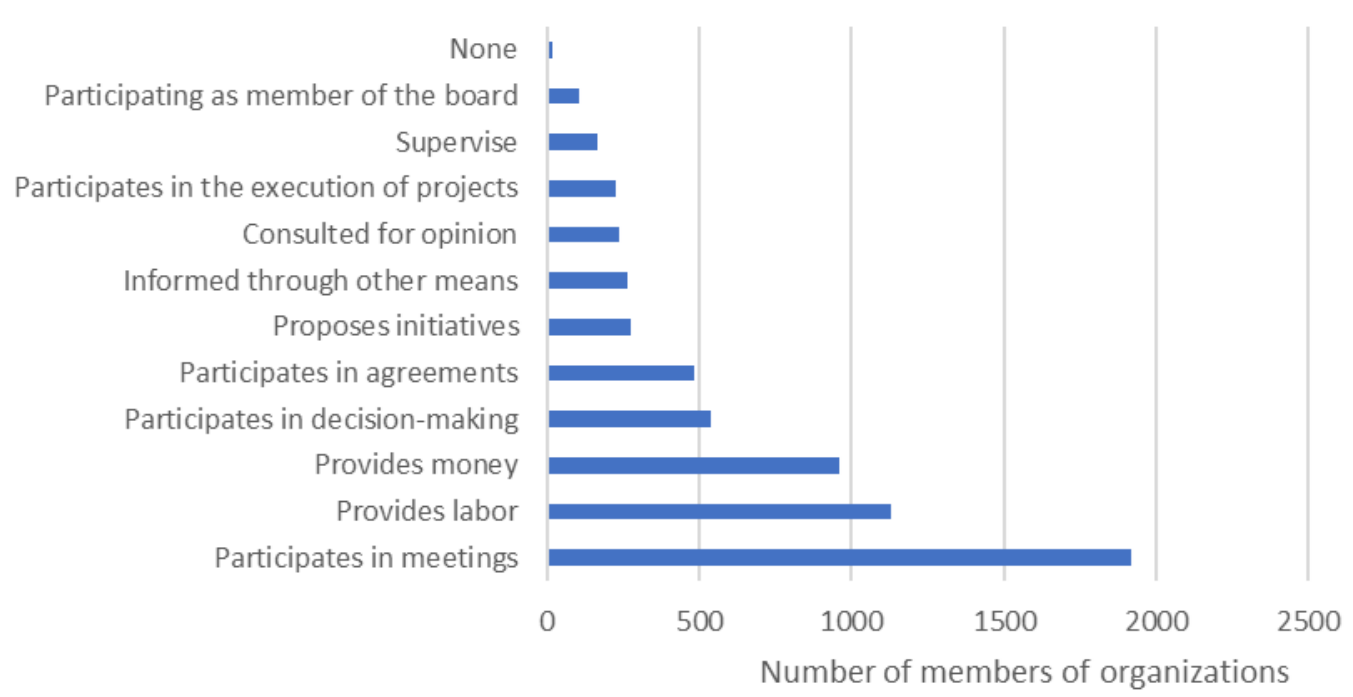

Figure 9. Activities carried out in the organization.

Testimonies of producers show that the problems of participation were due to a lack of capacity to adequately assume their organizational roles, as well as some disbelief about the culmination of the projects. Illiteracy and the difficulty of grassroots' members to express themselves publicly also influenced project participation, as well as precarious economic situations, which made it difficult for them to stop working on their farms to meet collective commitments. Low participation of the base brought counterproductive effects due to a low incidence in decision-making, restrictions on assuming managerial positions, a weakening of dialogue with public entities, and a lack of critical capacity to exercise social control and accountability.

Regarding leadership, although the members of the base recognized the importance of managers, they also expressed concern about the presence of permissive and ineffective leaders in the fulfillment of agreements. Those who did not know the functions of their position or who did not show initiative were questioned: "The attitude of the managers had been passive. Until they saw that construction was a fact, they then began to participate" (Interviewee 3).

However, the criticism of leaders whose actions were based on power relations that led to un-consulted decisions, authoritarian positions, lack of accountability, lack of clarity in the information provided, and poor receptivity for the solution of concerns (Interviewee 4), was even more common.

The link of the members of the board with the social, political, and institutional environment of the organizations was also a reason for the disputes with the base in which the leaders related to the political class. The incidence of this group became a factor in favor or against the organizations, according to the political line adopted by the leaders. Their support was an initial filter, sometimes definitive, to have the financial support of the territorial administrations, which was an essential requirement to access public incentives at the national level. The evidence indicated that these relationships, motivated by personal interests, weakened collective action because of inadequate management.

Faced with the absence of agreements among its members, the organizations depended on initiatives guided by individual criteria that negatively impacted group cohesion. The management of these problems was hindered by the short organizational trajectory, its internal fracture, and its biased conformation toward obtaining public resources without creating conditions for enduring collective action. Likewise, this was affected by the passivity of the bases that show the key role of managers, but also the absence of appropriate leadership. 


\subsubsection{Human Values}

The construction of the districts was the most tangible achievement of the members of the organizations, which, for many, was a surprising result for its magnitude and meaning. Above all, it represented a process of personal and collective learning that confronted the prevailing individualistic biases.

The collective work generated spaces for the recognition and strengthening of human values. Users said they learned to be more tolerant and to respect and share. Communication problems did not prevent progress toward learning how to communicate assertively. In the words of a member: "We have learned to respect each other. This has been a learning by necessity, because we are realizing that, if we affect others, we are going to be affected" (Focus Group 6).

Regarding the relationship between organizations and the State, for some leaders, it was important to strengthen ties with national and territorial entities, since it generated a feeling of trust. In fact, some communities received, for the first time, an investment that responded to their needs, which strengthened credibility in the State.

Collective awareness and formation of values were also expressed in constructing a sense of community and, in a more explicit vision, of water as a common good. These aspects, determinants for the operation and sustainability of the irrigation districts, were also appreciated for their future usefulness in claiming community interests.

However, in practice, behaviors were detected that indicated that the progress made in the formation of a collective conscience was still incipient. It should be noted that there was a lack of joint responsibility in the management of the districts, expressed by the inclination of the majority $(77 \%)$ toward payment of fees lower than the operating costs, and even toward non-payment of the service $(12 \%)$. In this regard, $66 \%$ of users said they were unaware of the operation of the district, $84 \%$ had not received training on irrigation management, $84 \%$ were unaware of the agreements on the frequency of access to water, and $92 \%$ on the fee to be paid for the service. These indicators reflect the problems of participation, leadership, and generation of agreements for collective work that organizations have faced since inception.

This indicates that collective action in irrigation was favored by certain variables, such as formation of values, that were not objectives of the policy, but which acquired relevance for members of organizations, as a result of their own experience.

\section{Discussion}

The results of the research show the importance of the human dimension for the analysis of collective action. Consequently, individual motivations, the formation and structuring of organizations, participation, leadership, human values, and socio-economic and institutional characteristics of the organizational context were defined as categories of analysis. These categories are specified in factors relevant to collective action, which are the main findings of this research.

The awareness of water as a common good is the first factor. Its absence in most cases explains, in large part, the bias of the associates toward the material dimension of the resource. However, it does not take into account the social and institutional dimensions, relevant from the integral perspective of the common good, exposed by Bollier [2].

This is related to the second factor that consists of the vision of the organizations by the members. Its connotation is instrumental. This is manifested by a motivation to associate with the sole purpose of accessing irrigation. This would lead us to think about the prevalence of an individual's direct and immediate interest in the face of water, which is valid in light of the rationality of the producers, but which, from a collective approach, would not represent a broader and a more far-reaching commitment to the organization. In fact, the low willingness to work associatively and the preference for individual work, even in the face of common problems such as commercialization and the precariousness of their economic situation, contrast with cooperative experiences that, due to a greater reach, have influenced rural poverty reduction [28,29]. In the universe of the producers involved in this research, collective 
work and the organization were not of particular interest, unless they represented an immediate individual benefit.

The formation of organizations is the third factor that needs to be highlighted. In a context in which collective work was not relevant, organizations were created to meet the requirements of the public call by following the guidelines of the State. If that conformation is induced by external demands and such organizations are established so that they only obey the sole satisfaction of policy requirements, which took place in the majority of the groups studied, the understanding of the organization by its members is largely determined by this type of gestation. Evidence suggests a substantive implication: a harmful dissociation within the organizations between leaders and grass roots directly affect organizational structuring and performance.

The previously mentioned information emphasizes the decisive role of leadership because of its impact on the orientation and scope of organizations from their formation throughout their operational process. Not only do leaders play a role as spokespersons, but also play roles in the cohesion and revitalization of social capital. This invites discussion about what Rojas [30] calls leadership for the community to differentiate it from leadership of the community. In the former information, the representatives work for the community, but, in some cases, they may be tempted to focus on their personal interests at the expense of the group [31]. In this regard, the investigation indicates the presence, on the one hand, of lax leaders that affected the fulfillment of the objectives and, on the other hand, of authoritarian leaders that generated power relations in which they cease to be representatives of the community, because of the exercise of their managerial positions without proper consultation with the base. Alternatively, leadership of the community seeks to strengthen social capital, as well as develop communication skills and human values such as responsibility, solidarity, respect, understanding, and trust. In other words, this means giving content and foundation to the organization beyond its formal structuring.

The development of these skills and values depends, according to Prieto and Fabelo [32], on the education of the leaders and the abilities of the associates to play an active role in their organizations.

This perspective corresponds to the dimension of human values, developed largely from relationships between people [33]. In the case of the organizations studied, it was found that, in effect, associative work contributed to the development of values, but also of individual capacities that had a positive impact on collective work. This is consistent with Mujawamariya et al. [34] who affirm that social capital and levels of trust are strengthened by increasing the participation of members in group decision-making. Therefore, strategies should be sought to foster participation and the development of capacities within organizations, so that, in their structure, human relations favorable to collective action prevail. This, in turn, is reinforced by participatory processes.

The fourth factor found corresponds to the nature of the organizational agreements. These should be relevant to the characteristics of the context and of the participants. However, because organizations limited themselves to establishing agreements for the construction and maintenance of physical works according to state requirements, it raises concerns about the little importance they gave to the social and institutional aspects necessary for water management. Following Ostrom [10], it is worth mentioning the relevance of agreements built by means of one's own and autonomous norms regarding the limits and conditions of the use of a natural resource, the responsibilities of the users, and the sanctions for non-compliance. These rules of the game, indispensable for the durability and solidity of collective action, determine the handling of conflicts between individual and collective interests. However, in the reality studied, due to the conditioning of agreements induced by the State, collective action fell short of the scope of the organizations, as expressed in the motivations of the members.

From these factors arises a concern as to whether associations could be organized in a more cohesive way and how their members could achieve more far-reaching motivations. Paradoxically, the key to solving the weaknesses of their collective action would be in the hands of the producers themselves. It is not for the State to do this, but it is for the State to create the conditions for it by providing public goods. 
A change would be expected from the producers. This change would result from their need to carry out successful initiatives, taking advantage of the new business opportunities offered by irrigation. This would mean that, instead of being policy instruments, they should use policies as an instrument of their organizations. To the extent that, with irrigation, their link with markets is strengthened and their incomes can improve. Their awareness of the importance of water resources in raising their quality of life increases, not only from a productive point of view, but also as an element of social cohesion.

For these producers, it would become imperative to agree among themselves and with others, in aspects such as the collective management of water and the type of productive activity in relation to crops, their marketing, and possible processing, among other options. Thus, the irrigation infrastructure would no longer be the main component, but part of a set directed toward a successful activity, which would give the organization a sense of greater reach and cohesion. The challenge for producers is to begin to internalize these aspects and integrate them into their organizations. As part of this, they must establish their own rules of organizational functioning with access to public policies they find appropriate.

However, within this optimistic view, it is necessary to pay attention to the conditions of the natural, economic, social, and political environment of the organizations which constitute the fifth factor of incidence in collective action.

It should be expressed that climate variability, inefficiency of traditional marketing systems, limited access to health and educational services, breaking of community ties, forced displacement, and fear of working collectively in an environment where the consequences of the armed conflict are difficult to predict, despite the agreement of peace between government and "guerrillas," indicate the adversity and complexity of the environment of the organizations studied.

To better understand the impact of violence on collective actions in the long term, it is pertinent to cite the work of Garcia et al. [35], according to whom armed conflicts affect local forms of collective action through changes in institutions and the manipulation of social capital. Therefore, groups outside the law can consolidate their own territorial strategies. Authority in these contexts tends to fragment, weakening state action. In that sense, members of the organizations perceived a disjointed action by the State and, therefore, demanded a presence with more comprehensive policies.

This adverse context generates what Cohen-chen and Van Zomeren [36] call low hope scenarios, in which people do not believe that collective action can generate important changes in their reality, because, without hope, there is no basis for the agency. In some irrigation organizations, there was skepticism, which weakened the performance of their managers. Thus, the distrust of members of the organizations was expressed in multiple ways including in the State, in themselves, and in their ability to transform their reality.

This discussion is not conclusive without highlighting the profound significance of the uncertainty in the actions and decisions of the organizations' members. For them, the future only exists as a mere expectation. It is not conceivable as a predictable possibility with some reliability or as a horizon of planning and personal projection. The uncertainty in which these rural settlers live, historically fueled by the instability of the environment, largely summarizes their perception of the countryside: the certainty of uncertainty. It is expressed in a "see to believe" behavior, or as García Márquez would say "a notion of life more similar to a practical method to distrust reality" [37] (p. X). However, if it turns out necessary, the search for uncertain opportunities in new horizons will become a reality. Hence, state policies must offer concrete solutions to real problems. The fact that access to public resources is an end in itself for some communities is a manifestation of the idea that the immediate is worth more than the desirable, even if it is not relevant.

\section{Conclusions}

In short, the complexity of rural life is overwhelming, and its crossroads are also expressed in organizations. The analysis of this reality highlights the need to complement technical solutions with 
human variables. Hence, it is important that the State and the organizations themselves become aware of the challenges of associating under these circumstances.

To understand the complexity, the methodology used was based on the construction of some categories of analysis to identify the factors that influence collective action. These categories were developed based on the results of the research and a theoretical framework in which the concepts of common good, collective action, social capital, and human capital were valuable inputs to achieve a systemic vision. The information obtained was organized according to the economic, social, and institutional characteristics of the producers, together with the characteristics of their collective work. These constituted the categories of the results achieved after analysis.

The results achieved allow us to answer the research question about the factors that limit collective action, validate the theoretical elements used, and highlight the need to deepen the categories of analysis and the factors examined. With the use of the mixed research method, a complement between qualitative and quantitative information was achieved, which enriched the analysis and contributed to a better approach to complexity based on the voices of the producers and their interpretation.

The investigation allows us to conclude that collective action in smallholder irrigation organizations is negatively affected by the following factors.

An incipient awareness of water as a common good, marked by a tradition of individual management without prior associative experience and without being subject to strict regulations. This lack of awareness represents a starting point of influence due to its role in determining the course. Because members of the organizations use water as a productive resource but not from a more integral perspective, a resource of common use and the interests of the group or of the beneficiary community and their management agreements do not acquire the relevance they deserve with respect to individual interests. This suggests that achieving a collective irrigation culture is not an immediate effect of belonging to a user organization but requires time and training over a long period.

An instrumental vision of organizations perceived exclusively as a means of accessing State funding resources and having an irrigation infrastructure. This is expressed in the motivations of the associates in which, although there is a discourse on collective and far-reaching purposes, the immediate and short-term private interests take precedence in practice. The lack of coherence between motivations that praise collective work and actions that prioritize personal interests restricts the scope of collective action.

A structuring of the organizations are limited to state and legal requirements, but without being concerned about establishing agreements that transcend the construction of the works. Therefore, they interpret the conditions and interests of their members. From this perspective, the organization acquires a strictly formal meaning. It seems that the central concern of the members is to comply with the legal requirements, by neglecting the organization itself in terms of its collective performance, its future projection, and its background scope, which are also not visualized. It is one thing to adapt to a format and another to use it to give it its own content with a strategic sense. This problem is aggravated by the absence of initiatives on the part of the State to support or accompany these more far-reaching purposes.

An internal division of organizations expressed in conflicts between directors and the members, caused mainly by mutual distrust. All the organizations have directors focused on performance, but who do not always enjoy sufficient credibility from usually indifferent, passive, or uninformed bases. This shows weaknesses in, and even absence of, leadership and participation. Then leadership and participation lose their cohesive power and become the opposite: a source of conflict. Overcoming this problem requires organizations to move toward community leadership, which is characterized by inclusivity. This requires replacing leadership that concentrates on the interests and power of managers.

The adverse conditions of the organizational context and the marginality of the associates reinforce the occurrence of the factors mentioned above, which generates a snowball effect. Individualism becomes a strategy of subsistence and risk minimization, while collective work is assumed as a requirement of public policy that, in theory, would serve the common purposes, but which, in practice, 
conflicts with prevention toward associativity and, in general, with the incipient formation of values and indispensable capacities for enduring collective dynamics.

The substantive contribution of this research lies in the identification and analysis of this set of factors relevant to collective action. It is hoped that they can be taken into account in other investigations, in which their importance will most likely vary according to the case studied. Likewise, this research highlights the importance of studying these factors in light of the categories of analysis used, so that a systemic approach that aids a better understanding of complexity is advanced.

Despite the difficulties encountered in irrigation organizations, this does not mean that communities do not have the capacity to manage their districts. However, as a basic condition for successful collective action, it is recommended to advance the examination of its determining factors, which requires the understanding of the organizations' environment and of the interests and capacities of their members. Although clear, this is an aspect that is not given sufficient attention, either by the organizations or by the supporting institutions. Thus, the focus of policy should not only be on building a physical infrastructure, but also on organizations as an end in themselves. Water governance is, above all, a long-term process that essentially involves the communities, their organizations, and their own capacities and agreements, within the framework of a state policy that supports them.

In this scenario, social cohesion has a positive impact on the administration and use of water for irrigation. However, it depends on the definition and acceptance by the members of the organizations of some shared purposes around initiatives that lead to new productive and commercial activities that improve their income and quality of life. Due to its decisive role in the achievement of these purposes, irrigation is also a factor of social cohesion and encouragement of collective work. This could generate a fruitful two-way relationship both between social cohesion and irrigation management.

In this work, the collective action was only examined during the construction phase of irrigation works. While this must be taken into account to avoid generalizations that do not take this specificity into account, it also invites the formulation of new questions for future research. In the stage of operation of the irrigation districts, what substantive changes may occur in collective action? What factors identified in this investigation lose importance or have already been resolved? What new factors influence collective action and acquire relevance for its durability and solidity? What weight or importance do regional differences have in collective action?

Author Contributions: J.P.M.-O. coordinated the research design, and the fieldwork and information analysis. The three authors designed the conceptualization and the methodological framework. R.G.-C. and P.S.-Z. conducted the direction and supervision, as well as the review and editing. J.P.M.-O. completed the analysis and writing. The team of the Complementary Irrigation Project of the Faculty of Agronomy of the Universidad Nacional de Colombia performed the fieldwork.

Funding: The Faculty of Agronomy of the Universidad Nacional de Colombia financed the fieldwork. The remaining parts of this research received no external funding.

Acknowledgments: Juan Patricio Molina-Ochoa is especially grateful to Nubia Milena Bayona for her contribution to the organization and the analysis of the information, to Camilo Lastra and Enrique Darghan for their support with statistical analysis, and to Felisa Ceña for her advice and guidance at the initial stage of the research. Authors are grateful to the small farmer irrigation organizations for their valuable information.

Conflicts of Interest: The authors declare no conflict of interest.

\section{References}

1. Añaños, M. La idea de los bienes comunes en el sistema internacional: Renacimiento o extinción? Anu. Mex. Derecho Int. 2014, 14, 153-195. [CrossRef]

2. Bollier, D. Pensar Desde los Comunes una Breve Introducción; Traficantes de Sueños, Cornucopia; Tinta Limón Ediciones: Madrid, Spain, 2016.

3. Miller, L. Acción colectiva y modelos de racionalidad. Estud. Front 2004, 5, 107-130.

4. Ostrom, E.; Gardner, R. Coping with Asymmetries in the Commons: Self-Governing Irrigation Systems Can Work. J. Econ. Perspect. 1993, 7, 93-112. [CrossRef] 
5. Poteete, A.; Janssen, M.; Ostrom, E. Trabajar Juntos: Acción Colectiva, Bienes Comunes y Múltiples Métodos en la Práctica, Primera ed.; Revista mexicana de sociología: Ciudad de México, Mexico, 2012; pp. 383-436.

6. Martínez, L.; Cielo, C. Bienes comunes y territorios rurales: Una reflexión introductoria. Eutopía 2017, 2007, 7-16. [CrossRef]

7. Hardin, G. La tragedia de los comunes. POLIS Rev. Latinoam 2005, 4, 1-14. Available online: http: //journals.openedition.org/polis/7603 (accessed on 19 June 2019).

8. Olson, M. La Lógica de la Acción Colectiva, Primera ed.; Editorial Limusa: Ciudad de México, Mexico, 1992.

9. Elster, J. La Explicación Del Comportamiento Social: Más Tuercas y Tornillos Para Las Ciencias Sociales; Gedisa: Barcelona, Mexico, 2010.

10. Ostrom, E. El Gobierno de Los Bienes Comunes, Primera ed.; Fondo de Cultura Económica: México D.F., Mexico, 2000.

11. Cárdenas, J.C. Dilemas de lo Colectivo Instituciones, Pobreza y Cooperación en el Manejo Local de Los Recursos de Uso Común, Primera ed.; Centro de Estudios sobre Desarrollo Económico, Universidad de los Andes: Bogotá, Colombia, 2010.

12. Fonseca, F.; Montalba, R.; García, M. Redes sociales, capital social y acción colectiva en dos territorios campesinos de la región de La Araucanía, en Chile, para enfrentar problemas asociados al acceso al agua. Pap. Rev. Sociol. 2015, 9004, 577-606. [CrossRef]

13. Ostrom, E.Y.; Ahn, T.K. Una perspectiva del capital social desde las ciencias sociales: Capital social y acción colectiva. Rev. Mex. Sociol. 2003, 65, 155-233. [CrossRef]

14. Garrido, S. Plenty of trust, not much cooperation: Social capital and collective action in early twentieth century eastern Spain. Eur. Rev. Econ. Hist. 2014, 18, 413-432. [CrossRef]

15. Millán, R. Capital social: Su papel en los dilemas de cooperación y la coordinación de acciones. Estudio Sociol. 2015, 32, 259-284. [CrossRef]

16. Lee, J.; Lee, H. Human capital in the long run. J. Dev. Econ. 2016, 122, 147-169. [CrossRef]

17. Pereira, G. Capacidades individuales y capacidades colectivas. Sistema 2006, 195, 35-51.

18. Gurney, G.G.; Cinner, J.E.; Sartin, J.; Pressey, R.L.; Ban, N.C.; Marshall, N.A.; Prabuning, D. Participation in devolved commons management: Multiscale socioeconomic factors related to individuals'participation in community-based management of marine protected areas in Indonesia. Environ. Sci. Policy 2016, 61, 212-220. [CrossRef]

19. Crane, B.; Hartwell, C.J. Global talent management: A life cycle view of the interaction between human and social capital. J. World Bus. 2019, 54, 82-92. [CrossRef]

20. Narváez, C. Asociaciones y cooperativas rurales: Factores internos y externos que influyen en su estabilidad y eficiencia. Una reflexión sobre el caso de Viotá, Cundinamarca. Coop. Desarro 2014, 22, 35-53.

21. Zabala, H. Economía Agraria y Asociatividad Cooperativa en Colombia; Funlam: Medellín, Colombia, 2016.

22. Aristizábal, C. El modus operandi de las organizaciones de productores agropecuarios en Risaralda, Colombia. Primera fase: Adaptaciones metodológicas y algunos resultados. Coop. Desarro. 2017, 111, 154-160.

23. Gutiérrez, J. Smallholders' Agricultural Cooperatives in Colombia: Vehicles for Rural Development? Rev. Desarro. Soc. 2014, 73, 219-271. [CrossRef]

24. Buendía-Martínez, A.; Côté, I. Desarrollo territorial rural y cooperativas: Un análisis desde las políticas públicas. Cuad. Desarro. Rural 2014, 74, 35-54. [CrossRef]

25. Bryman, A. Social Research Methods; Oxford University Press: New York, NY, USA, 2016.

26. Angrosino, M. Recontextualización de la observación. In Métodos de Recolección y Análisis de Datos; Denzi, N., Ed.; Editorial Gedisa: Barcelona, Spain, 2015; pp. 203-234.

27. El Congreso de Colombia. Ley 160 de 1994. Cápitulo 9 Artículo 38; El Congreso de Colombia: Bogotá, Colombia, 1994.

28. Ma, W.; Abdulai, A. Does cooperative membership improve household welfare? Evidence from apple farmers in China. Food Policy 2016, 58, 94-102. [CrossRef]

29. Mutonyi, S. The effect of collective action on smallholder income and asset holdings in Kenya. World Dev. Perspect. 2019, 14, 1-7. [CrossRef]

30. Rojas, R. El liderazgo comunitario y su importancia en la intervención comunitaria. Psicol. Para Am. Lat. 2013, 25, 57-76.

31. Lopez, A.C. Making 'my' problem 'our' problem: Warfare as collective action, and the role of leader manipulation. Leadersh. Q. 2019, in press. [CrossRef] 
32. Prieto, R.A.; Fabelo, R.A. Liderazgo y capital social: Uso de redes como herramienta para el desarrollo sostenible. Telos 2009, 11, 52-68.

33. Sarkki, S.; Ficko, A.; Miller, D.; Barlagne, C.; Melnykovych, M.; Jokinen, M.; Soloviy, I.; Nijnik, M. Human values as catalysts and consequences of social innovations. For. Policy Econ. 2019, 104, 33-44. [CrossRef]

34. Mujawamariya, G.; D'Haese, M.; Speelman, S. Exploring double side-selling in cooperatives, case study of four coffee cooperatives in Rwanda. Food Policy 2013, 39, 72-83. [CrossRef]

35. Garcia, L.M.; Avila, H.; Gutierrez, R.R. Land-use and socioeconomic changes related to armed conflicts: A Colombian regional case study. Environ. Sci. Policy 2019, 97, 116-124. [CrossRef]

36. Cohen-Cheny, S.; Van Zomeren, M. Yes we can? Group efficacy beliefs predict collective action, but only when hope is high. J. Exp. Soc. Psychol 2018, 77, 50-59. [CrossRef]

37. Llinás, R. El Cerebro y el Mito Del yo; Editorial Norma: Bogotá, Colombia, 2002.

(C) 2019 by the authors. Licensee MDPI, Basel, Switzerland. This article is an open access article distributed under the terms and conditions of the Creative Commons Attribution (CC BY) license (http://creativecommons.org/licenses/by/4.0/). 